鈴木 直弘 中林成一郎

中塚 滋

高坂 知節

東北大学医学部耳鼻咽喉科学教室

\section{鼻アレルギー患者の鼻汁中および鼻粘膜組織中の 各浸潤細胞の免疫組織学的検討}

通年性鼻アレルギ一患者を対象として, 鼻腔洗浄液扔よび鼻粘膜組織中の各浸 潤細胞を免疫組織学的に比較検討した。ささらに抗原チャレンジ即時相における各 浸潤細胞を同時に検討した。その結果, 鼻腔洗浄液中と鼻粘膜組織中では, 各浸 潤細胞は数，分布とも大きく異なった。そうのため各浸潤細胞は，それぞれの部位 で各自の生理学的な役割を,複雑なネットワークを形成しながら, I 型アレルギー 反応に関与していると推察された。

キーワード：鼻アレルギー, 鼻粘膜, 免疫染色, $\mathrm{EG}_{2}$ 陽性細胞
はじめに

アレルギー性鼻炎はくしゃみ，水性鼻汁，鼻閉を 3 主 徵とするI 型アレルギーの代表的疾患である. 即時相の 発症には IgE, 肥満細胞の系が重要であり, 感作の成立し た個体に再び同一抗原の侵入があった時，その抗原は鼻 粘膜に存在する $\mathrm{IgE}$ 抗体感作肥満細胞と反応し, 肥満細 胞からヒスタミン，ロイコトリエン(LTs)，プロスタグ ランデイン $(\mathrm{PG})$, 血小板活性化因子 $(\mathrm{PAF})$, 好酸球遊

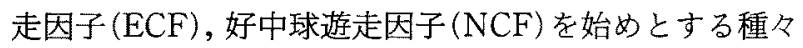
の化学伝達物質が放出されアレルギー性鼻炎の 3 主徴が 出現する。それに対して，抗原誘発 7〜10時間後に鼻閉 を中心とする症状の再増悪（遅発型反応）を認める症例 もあり遅発型反応時の鼻腔洗浄液中には, 好酸球, 特に 活性型好酸球（EG2 陽性細胞）及び好中球の增加を認め る. I 型アレルギーの成立には肥満細胞以外にも Tリン パ球， Bリンパ球，マクロファージ，好酸球，好中球が 重要な役割を担っているが, 鼻汁中及び鼻粘膜組織中に おけるこれらの各浸潤細胞を比較検討した報告は少な い.

そこで通年性鼻アレルギー患者を対象として鼻腔洗浄

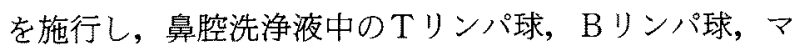
クロファージを ABC-ALP 法により免疫染色を行い, 更 に鼻粘膜組織中における各浸潤細胞を同様に免疫染色に より検討し，各浸潤細胞の鼻粘膜における分布を明らか にし，抗原誘発即時相に扔ける各浸潤細胞の変化を検討 し若干の知見を得たので報告する。
研究方法

\section{1. 対象}

皮内反応, 抗原鼻粘膜誘発試験, CAP-RAST, 鼻汁中 好酸球検查のうち少なくとも2 項目以上陽性を示した, 通年性鼻アレルギー患者 7 例を対象とした．各症例に対 し，鼻腔洗浄および鼻粘膜採取を施行した。鼻腔洗浄は， H，D(ダニ)ディスク 3 枚による抗原チャレンジを行い， チャレンジ前とチャレンジ30分後に鼻腔洗浄を施行し た。また鼻粘膜組織は一側の下甲介粘膜に同様にチャレ ンジを行い, 30分後に採取した. 対側は, 事前に対照ディ スクを置き，非特異的反応が起こらないことを確認した 上で，チャレンジ (ー) 側（コントロール側）として採 取した，鼻粘膜は，広範囲下甲介切除術にて得られた下 甲介粘膜を用い，患者の承諾を得た上で抗原チャレンジ を行った。

\section{2. 鼻腔洗浄法}

鼻腔洗浄は, $37^{\circ} \mathrm{C}$ 加温生理食塩水を各鼻腔に $5 \mathrm{ml}$ ずつ 計 $10 \mathrm{ml}$ 注入しその後, 頭部を前屈し注入液を回収し, 回 収液に EDTA 加PBS および Dithiothreitol を加元䚌汼 後，室温に 30 分間静置し遠心した $(1500 \times \mathrm{g})$ ．上清は， $\mathrm{ECP}$ 測定のため $-80^{\circ} \mathrm{C}$ に凍結保存し，沈渣に PBS を加 え䚇汼後同液に Hinkelman 液を加元血球計算盤にて総 細胞数を算定後, $0.5 \%$ Albumin 液を加えサイトスピン （800rpm 5 分間）を行いスライドグラス標本を作製し た.作製した標本を15分間冷アセトンにて固定後, ABCALP 法にて免疫染色を行った。染色の方法は，スライド グラス標本をPBSにて 3 回洗浄後，5\%正常ウマ血清 にて30分間非特異的反応を阻止しPBSにて 3 回洗浄 


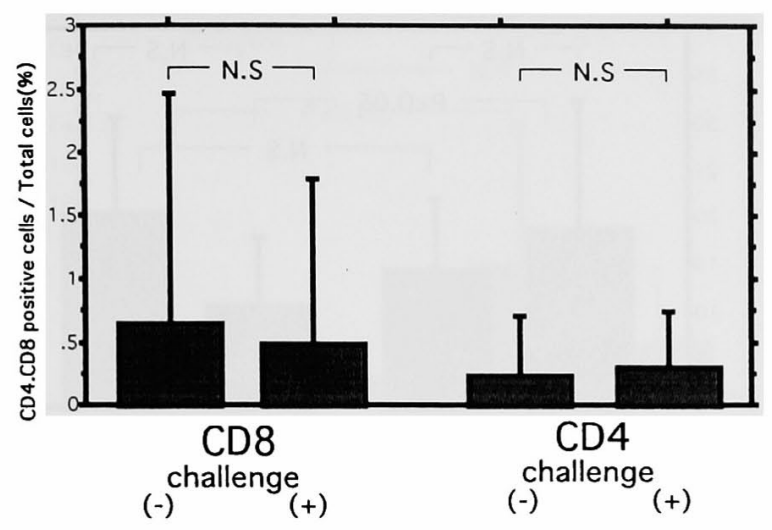

図 1 鼻腔洗浄液中の CD4.CD8 陽性細胞 CD4.CD8 陽性細胞は, 総細胞の $1 \%$ 以下で CD8 陽性細胞がやや優位であった。抗原 チャレンジによる増加は認めなかった。 Mean \pm S.D.

後, 各モノクローナル抗体と $4^{\circ} \mathrm{C} 24$ 時間反応させた。使 用したモノクローナル抗体は，Leu2a (CD8), Leu3a (CD4), Leu14 (CD22) (BECTONDICKINSON, USA), anti human macrophage (CD68) (DAKO JAPAN Co, Ltd），抗ヒト分泌型 ECP 抗体（EG2）（Pharmacia）を 用いた. 1 次抗体反応終了後, PBS にて 3 回洗浄後 2 次 抗体としてウマ抗マウス IgG 抗体 (VECTOR, USA) と 室温60分間反応後 PBS で 3 回洗浄 ᄂ ALPlabeled Avidin（DAKO JAPAN Co, Ltd）にて30分間 室温反応後, ALP 反応を行った. 反応終了後, PBS にて 3 回洗浄し， $20 \%$ ホルマリンにて10分間後固定し，水洗 後マイヤーのへマトキシリン液にて核染し, 風乾後キシ ロール透徹ののち封入した。陰性コントロールは，マウ ス血清で染色されないことを確認し，陽性コントロール は, 扁桃摘出術にて得られたヒトロ口蓋扁桃を用いた。

\section{3. 鼻粘膜免疫染色法}

手術的に得られた標本を直ちに $4 \%$ パラホルアルデ ヒドに浸し，マイクロウェーブ処理後同液にて $4{ }^{\circ} \mathrm{C} 4$ 〜 6 時間固定し $10 \% ， 20 \%$ sucrose 加PBSにてそれぞれ 浸透後 O.C.T compound に包埋し $-80^{\circ} \mathrm{C}$ に凍結保存し た.クライオスタットにて $6 \mu \mathrm{m}$ の凍結切片を作製し, 鼻 腔洗浄と同様に免疫染色を行った。なお使用したモノク ローナル抗体は, Leu 2a (CD8), Leu 3a (CD4), Leu 14 (CD22), anti human macrophage (CD68), anti human neutrophil elastase (DAKO JAPAN Co Ltd), 抗七ト分泌型 ECP 抗体 (EG2), anti human-Major basic protein (BMK-13) (ニチレイ)を用い, 同様に免 疫染色を行った。

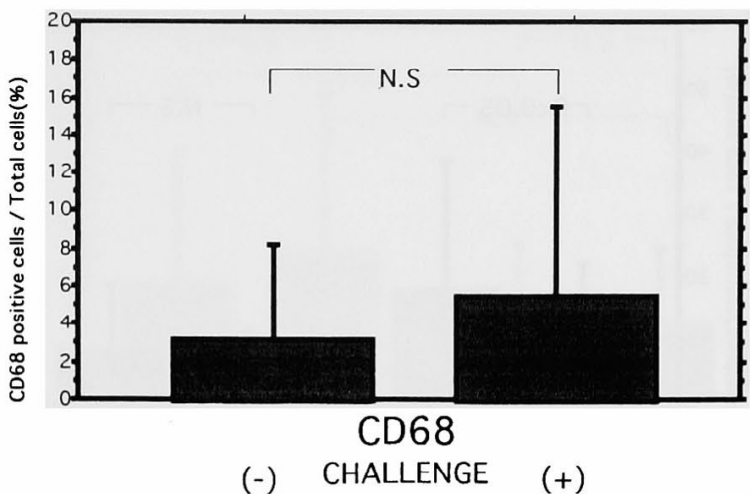

図 2 鼻腔洗浄液中の CD68 陽性細胞 CD68 陽性細胞は, 総細胞の3.65土1.9\%に 認め，抗原チャレンジにより増加傾向を認 めた。

$(\mathrm{P}=0.1) . \quad$ Mean \pm S.D.

\section{4. 評価及び統計学的処理}

サイトスピン標本では，全有核細胞に対する各陽性細 胞の割合を示し，鼻粘膜標本は，観察部位は各切片とも 上皮層，粘膜固有層，分泌線周囲，深部血管層に分け観 察を行った。

その結果,粘膜固有層に有意に細胞浸潤を認めたため, 粘膜固有層を中心に観察を行った。更にこの粘膜固有層 を上皮基底層直下の浅層及び分泌腺までの深層の二層に 分け観察を行った。比較的均一に細胞が分布している部 位を各切片とも 5 視野抽出し，全有核細胞に対する各陽 性細胞の割合を平均して示した。な抢各数值は，平均士 標準誤差で表し，統計は $\mathrm{t}$ 検定または Wilcoxon 検定を 用いた。

\section{結果}

1. 抗原チャレンジ後, 即時相における鼻汁中各浸潤 細胞の変化

CD4，CD8 陽性細胞は，それぞれ0.30土0.2，0.71土 $0.7 \%$ と総細胞の $1 \%$ 以下で CD8 陽性細胞がやや優位に 浸潤し,ともにチャレンジによる増加は認めなかった(図 1)。CD22 陽性細胞は，鼻汁中にはほとんど認めず， CD68 陽性細胞は, 総細胞の3.65 $1.9 \%$ 浸潤し，チャレ ンジにより $5.92 \pm 3.9 \%$ と増加傾向を認めた $(\mathrm{P}=0.1)$ (図 2 )。好酸球は, 総細胞の $10.30 \pm 5.1 \%$ 浸潤しチャレ ンジにより19.27 $\pm 7.8 \%$ と有意に増加し $(\mathrm{P}<0.05)$, 好 中球は, 総細胞の $5.26 \pm 2.6 \%$ 浸潤し,チャレンジにより $9.42 \pm 3.8 \%$ と有意な増加は認めなかった $(\mathrm{P}=0.2)$ (図 3 ). EG2 陽性細胞は，総細胞の0.19 $00.1 \%$ 浸潤し チャレンジにより $0.79 \pm 0.4 \%$ と増加傾向を示した $(\mathrm{P}=$ 0.09).また, 好酸球の顆粒蛋白の 1 つの ECP は, $2.51 \pm$ 


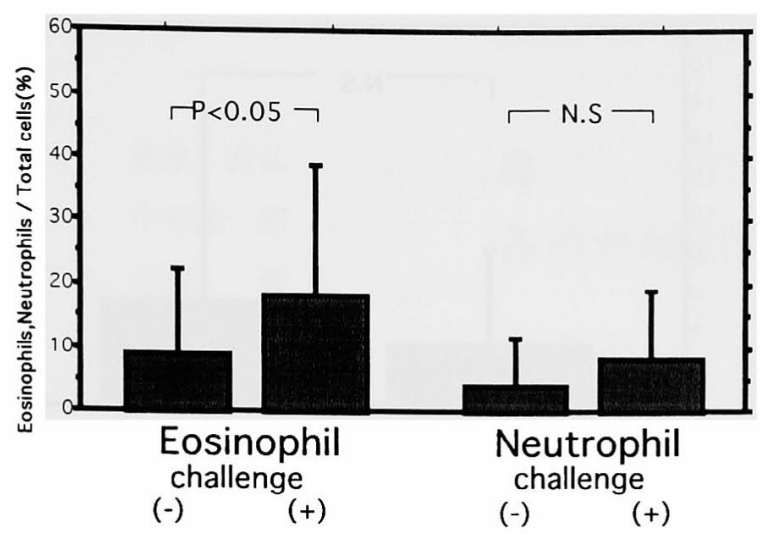

図 3 鼻腔洗浄中の好酸球, 好中球

好酸球は，抗原チャレンジにより有意に増 加したが, 好中球は有意な増加は認めな かった。

Mean \pm S.D.

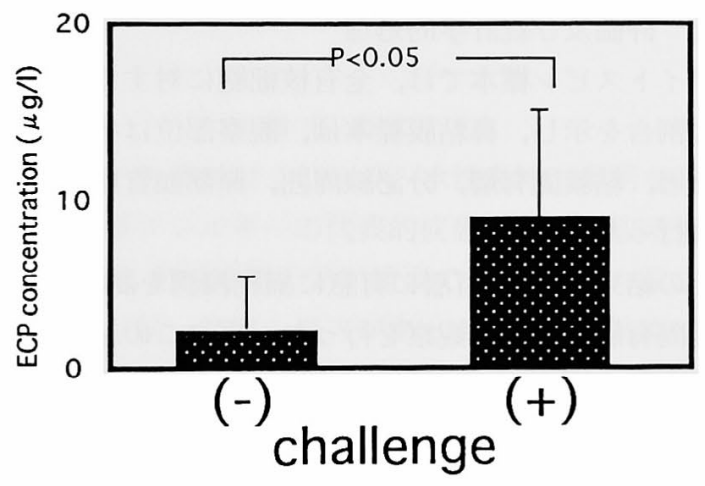

図 4 鼻腔洗浄液中の ECP 濃度

鼻腔洗浄液中の ECP 值は, 抗原チャレン ジ30分後に有意に増加した. Mean士S.D.

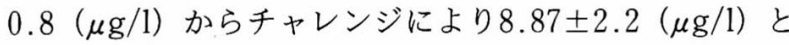
有意に鼻汁中に増加した（図 4 ）.

2. 抗原チャレンジ後, 即時相における鼻粘膜組織中 の各浸潤細胞の変化

CD4 陽性細胞は, 固有層浅層で総細胞の19.58土 $5.2 \%$, 深層では $11.53 \pm 2.7 \%$ と浅層に有意に浸潤してお り $(\mathrm{P}<0.05)$, ともにチャレンジにより有意な変化は認 めなかった（図 5 ). CD8 陽性細胞は，浅層で総細胞 $6.23 \pm 1.8 \%$ ，深層では7.68土2.3\%とほぼ均一に浸潤し ておりともにチャレンジによる変化は認めなかった (図 6 ).なお $\mathrm{CD} 4 / \mathrm{CD} 8$ は, 粘膜固有層全体で1.9〜3.0で CD4 陽性細胞が優位に浸潤した.CD22 陽性細胞は, 浅層 で層細胞 $0.88 \pm 0.4 \%$ ，深層では $7.30 \pm 2.8 \%$ と深層に有 意に浸潤し $(\mathrm{P}<0.05)$ ，ともにチャレンジによる変化は 認めなかった（図 7 )。CD68 陽性細胞は, 浅層で総細胞 の $11.40 \pm 1.8 \%$ ，深層では11.73土1.9\%と浅層，深層に

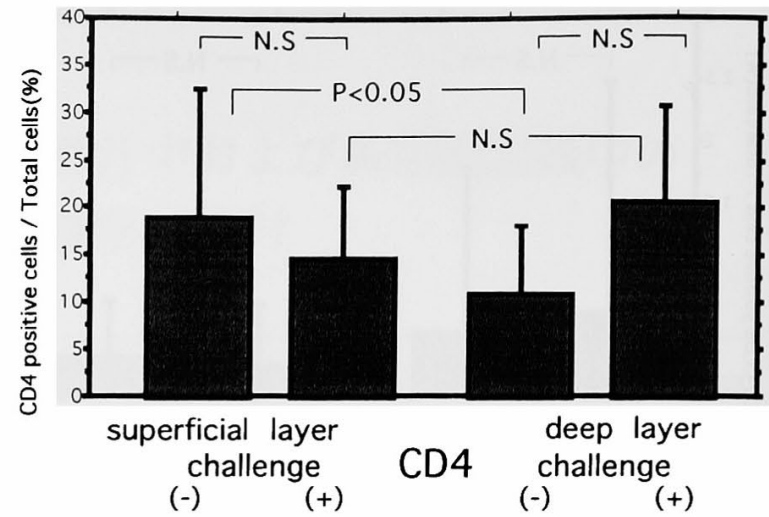

図 5 粘膜固有層における CD4 陽性細胞 CD4 陽性細胞は，抗原チャレンジ (一) で は浅層に有意に増加し，抗原チャレンジに より有意な変化は認めなかった。 Mean \pm S.D.

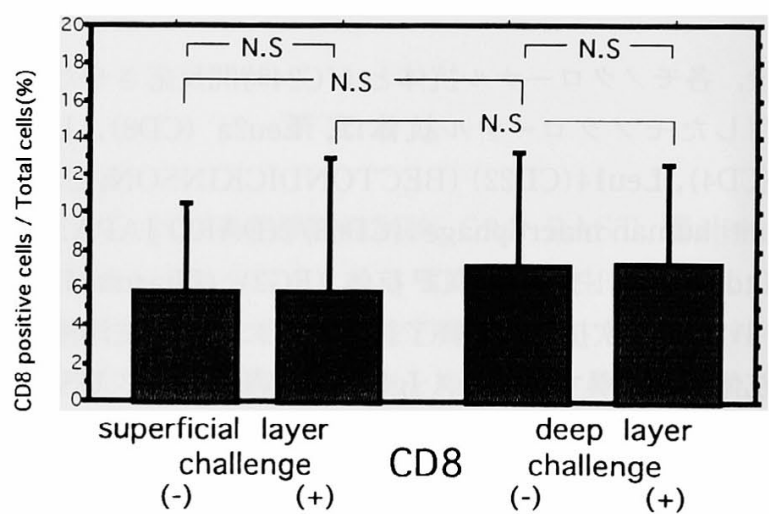

図 6 粘膜固有層における $\mathrm{CD} 8$ 陽性細胞 CD8 陽性細胞は, 粘膜固有層全体に均等に 浸潤し，抗原チャレンジによる変化は認め なかった. Mean士S.D.

ほぼ均一に浸潤し，ともに，チャレンジによる変化は認 めなかった（図 8 )。

Neutrophil elastase 陽性細胞は, 浅層では総細胞の $6.30 \pm 2.8 \%$ ，深層では $3.51 \pm 1.9 \%$ と浅層に有意に浸潤 し $(\mathrm{P}<0.05)$ ，ともにチャレンジによる有意な変化は認 めなかった(図 9，10)。EG2 陽性細胞は, 浅層で総細胞 の $8.10 \pm 1.4 \%$ ，深層では $4.90 \pm 1.8 \%$ と浅層に有意に浸 潤し $(\mathrm{P}<0.05)$ ，チャレンジにより浅層で12.60土1.6\% と有意に増加を認めた $(\mathrm{P}<0.05$ ) (図 11,12$)$ ．なお EG2 陽性率は，上皮直下に帯状に浸潤しそのほとんどが脱顆 粒を認め, 総好酸球の EG2 陽性率は, 約 $80 \%$ であった。

考察

本研究で示したように, 鼻腔洗浄液中の各浸潤細胞を 


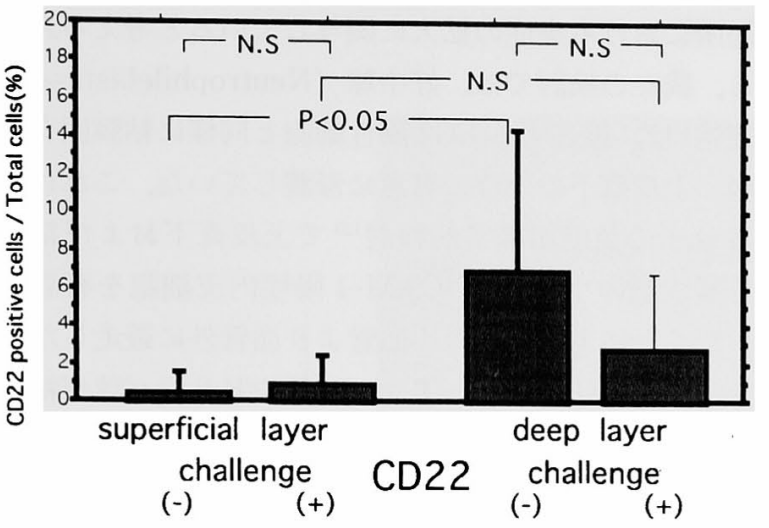

図 7 粘膜固有層における CD22 陽性細胞 CD22 陽性細胞は，抗原チャレンジ (一) で は, 深層に有意に浸潤し, 浅層, 深層とも 抗原チャレンジによる変化は認めなかっ た. Mean \pm S.D.

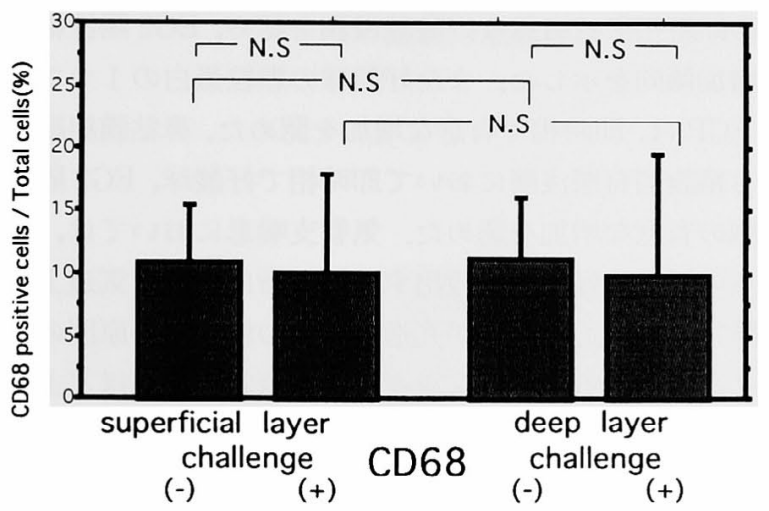

図 8 粘膜固有層における CD68 陽性細胞 CD68 陽性細胞は, 粘膜固有層浅層, 深層に 均一に浸潤し, 抗原チャレンジによる変化 は認めなかった. Mean土S.D.

免疫染色した結果, 鼻汁中の細胞は, 鼻粘膜組織中とは かなり異なり CD22 陽性細胞 (Bリンパ球) は，鼻汁中に はほとんど認められず, CD4, CD8 陽性細胞（Tリンパ 球) は総細胞の $1 \%$ で, CD8 陽性細胞が優位であった。 これは Okuda らが1)233) 鼻粘膜上皮層におけるリンパ球 を検討し Bリンパ球は認められずTリンパ球のみ浸潤 し, CD8 陽性細胞が CD4 陽性細胞より優位で CD4/CD8 比が約 0.5 であると報告しているが, 鼻汁中の CD4, $\mathrm{CD} 8, \mathrm{CD} 22$ 陽性細胞の割合は, 鼻粘膜上皮層のこれらの 細胞の割合と一致することが判明した. 鼻汁中のTリン パ球は, 総細胞の $1 \%$ 以下しか浸潤しておらず，また抗 原チャレンジによる影響が認められないことにより，鼻 汁中ではさほど重要な働きはしていないのではないかと 推察される。それに対し, CD68 陽性細胞(マクロファー

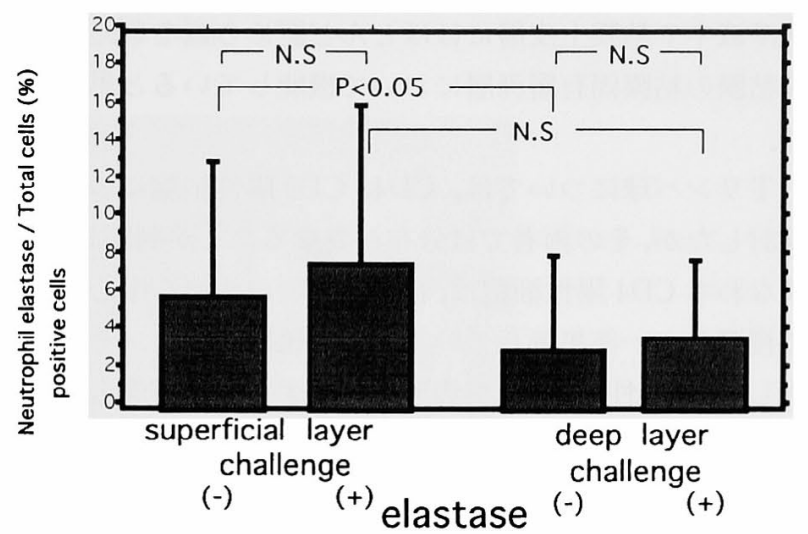

図 9 粘膜固有層における Neutrophil elastase 陽性細胞

Neutrophil elastase 陽性細胞は, 抗原チャ レンジ (一) では, 粘膜固有層浅層に有意 に浸潤し，抗原チャレンジによる有意な増 加は認めなかった。 Mean \pm S.D.

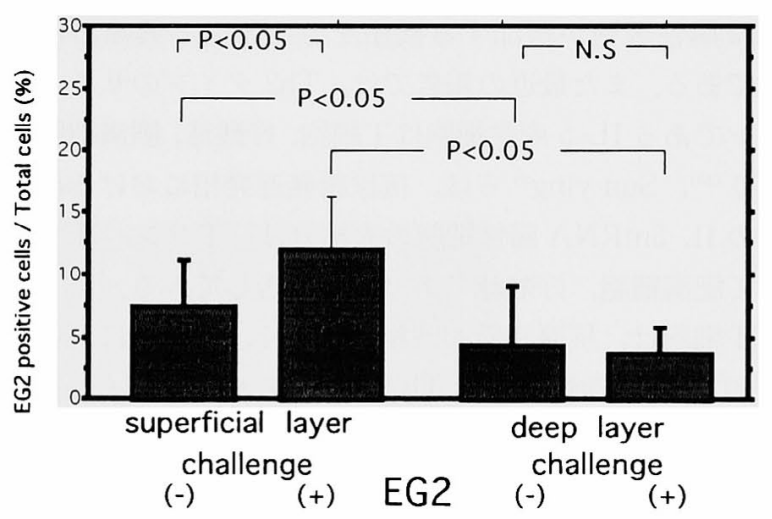

図10 粘膜固有層における EG2 陽性細胞 EG2 陽性細胞は, 粘膜固有層浅層に有意に 増加し，抗原チャレンジにより浅層で有意 に増加した. Mean士S.D.

ジ）は，総細胞の約 $3 \%$ ぼ浸潤しており， Sigurdur ら も ${ }^{4)}$ 花粉症患者に季節外に抗原チャレンジを行い鼻汁中 のマクロファージを免疫染色し, 総細胞の $0.5 \%$ に認め, チャレンジ 4 時間後に有意な増加を認めたと報告してい る.マクロファージは抗原チャレンジ即時相ではなく, 遅発相に増加する可能性もあり今後の課題としたい.

続いて鼻粘膜における各浸潤細胞を検討した結果, 鼻 汁中とは明らかに浸潤細胞数やその分布が異なった。ま ず CD22 陽性細胞 (Bリンパ球) は, 粘膜固有層の比較的 深層, 鼻腺周囲に有意に浸潤しており, 抗原チャレンジ 即時相では有意な変化は見られなかった。

下甲介粘膜において $\operatorname{IgE}$ 抗体産生が行われているか どうかは不明であるが，少なくとも Bリンパ球は，鼻腔 
洗浄液中や粘膜上皮層にはほとんど認められないため, 鼻粘膜の粘膜固有層樑層において機能していると思われ た.

Tリンパ球については，CD4, CD8 陽性細胞について 検討したが，その両者では分布が異なることが判明した。 すなわち CD4 陽性細胞は, 粘膜固有層の浅層を中心とし て浸潤し，一部集簇している部位も確認できた。それに 対し CD8 陽性細胞は, 集簇形成はせず粘膜固有層全体に びまん性に均一に分布していた。CD4 陽性細胞は, 抗原 チャレンジ遅発相に打いて有意に増加したとの報告が見 られる ${ }^{5}$. Th2 細胞の産生する IL-4, IL-5 は特に I 型ア レルギーにおいて重要で IL -5 は, 好酸球の血管内皮細 胞への接着を六進し好酸球の遊走活性も持つ.また抗原 誘発遅発相に扔いてTh2夕イプのサイトカインの mRNAの発現を観察した報告もあり ${ }^{6)}$ この中で EG2 陽性細胞と IL-5mRNA 発現細胞との間に有意な相関を 認めたとしている。こ机は，抗原誘発後遅発相に扔ける EG2 陽性細胞が增加する機序を考える上で興味ある知 見である.また最近の報告では，Th2タイプのサイトカ インである IL-5 産生細胞はT細胞, 好酸球, 肥満細胞で あり ${ }^{78)}$, Sun ying ${ }^{93}$ らは, 抗原誘発遅発相に扔ける鼻粘 膜の IL-5mRNA 陽性細胞の大部分は, Tリンパ球で続 いて肥満細胞，好酸球であったと報告している，以上よ り T細胞㹥，抗原誘発即時相ではなく，遅発相に扔いて 増加し, 更に活性化されTh2 タイプのサイトカインを放 出し，その IL-5 を始めとするサイトカインが鼻粘膜局 所に好酸球を誘導し活性化するので流ないかと推測され る.

樹状細胞は, 生体内に広く存在しておりクラスII抗原 を発現し抗原提示細胞としての役割を担っている.ラン ゲルハンス細胞やマクロファージがこの細胞に含まれる が鼻粘膜にはランゲルハンス細胞は存在しないとされて 㧈り ${ }^{10)}$, マクロファージが抗原提示細胞として鼻粘膜で は機能していると思われる. 我々の検討では, 粘膜固有 層の総細胞の約10\%ほど存在し, 粘膜上皮層から固有層 深層までびまん性に分布し，抗原チャレンジ即時相では 有意な増加は認めなかった。また連続切片を作製したと ころ, 鼻粘膜に存在するマクロファージの大部分が HLA-DR 陽性を示し, 活性化し存在していることが確 認できた。

好中球は, 生体内に扔ける防御機構が成立する上で重 要な役割を演じている.すなわち生体内で何らかの侵襲 が加わったり, 感染炎症が起こった場合, 血管内皮細胞 に粘着しその後, 血管外に遊出し病巣に向かい遊走を始 める。 そこで好中球は, 種々のケミカルメディエーター

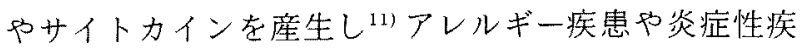

患局所に扔ける炎症の拡大に関与していると考えられて いる. 我々の検討では，好中球 (Neutrophilelastase 陽 性細胞）は，後述する EG2 陽性細胞と同様に粘膜固有層 浅層の上皮直下の部位に有意に浸潤していた。これは， 接着分子の免疫組織学的検討 ${ }^{12)}$ で上皮直下および粘膜 固有層浅層の小血管に ICAM-1 陽性内皮細胞を有意に 認めたことにより，この小血管より血管外に遊走したと

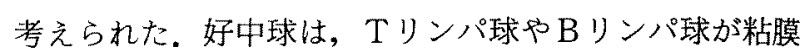
固有層内にとどまり鼻汁中にはほとんど遊走してこない のに対し，抗原チャレンジ後に比較的早期より鼻汁中に 遊走し，特に遅発相において増加傾向を示すことにより 炎症の遷延化, 慢性化の一因を担っているのではないか と推察される.

通年性鼻アレルギー患者の鼻腔洗浄液中または鼻粘膜 組織中には, 抗原チャレンジ以前よりかなりの好酸球浸 潤を認める。そこに抗原チャレンジを行うと鼻腔洗浄液 中の即時相では有意な好酸球浸潤を認め, EG2 陽性細胞 は増加傾向を示した。また好酸球の顆粒蛋白の1つであ る ECPは, 即時相で有意な増加を認めた。鼻粘膜組織中 でも粘膜固有層浅層において即時相で好酸球, EG2 陽性 細胞の有意な堌加を認めた。気管支喘息に扔いては, こ れらの活性型好酸球が放出する顆粒蛋白により気道上皮 が障害され気道過敏性が方進し炎症の慢性化の原因の 1 つとされている。鼻アレルギーでは気管支喘息ほど上皮 障害は強くないとされているが13), 鼻粘膜の腫脹の強い 浮腫状の形態を示寸症例の粘膜上皮細胞は, 比較的剥脱 しやすい傾向を認めた，ただしこれは，光顕レベルでの 検討であるため, 今後電䫓レベルで詳細に検討を加えた いと思う．粘膜固有層浅層の好酸球は，そのほとんどが 脱顆粒を認め,さらに好酸球の $\mathrm{EG} 2$ 陽性率を検討したと ころ, 約 80 ～90\%であった。また粘膜固有層深層の好酸 球は比較的安定した形態を保ち脱顆粒は軽度であった。 そのため, 粘膜固有層浅層に浸潤した好酸球は, 顆粒蛋 白を放出し脱顆粒を起こしその場で好酸球自体の機能を 果たしていると思われた。 それに対し鼻腔洗浄液中の好 酸球の EG2 陽性率は, 即時相で約 $30 \%$, 遅発相で約 $40 \%$

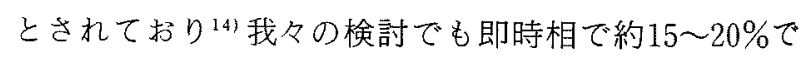
あった.鼻粘膜組織中では約 $80 \%$ の好酸球が EG2 陽性を 示すのに対し鼻腔洗浄液中では陽性率が約 $30 \%$ と低くな る理由として考元られるのは, 一つは活性化していない 好酸球が選択的に鼻粘膜組織中から鼻汁中へ遊走するか また, 鼻腔洗浄液中の好酸球は, 顆粒蛋白を放出し脱顆 粒が著明なためモノクローナル抗体と反応しなかったた めと考えられる。前者は, 鼻粘膜局所でのI 型アレルギー 反応で活性化していない好酸球だけが鼻汁中へ遊走する とは考えにくく後者が妥当と思わ机る，好酸球は，粘膜 


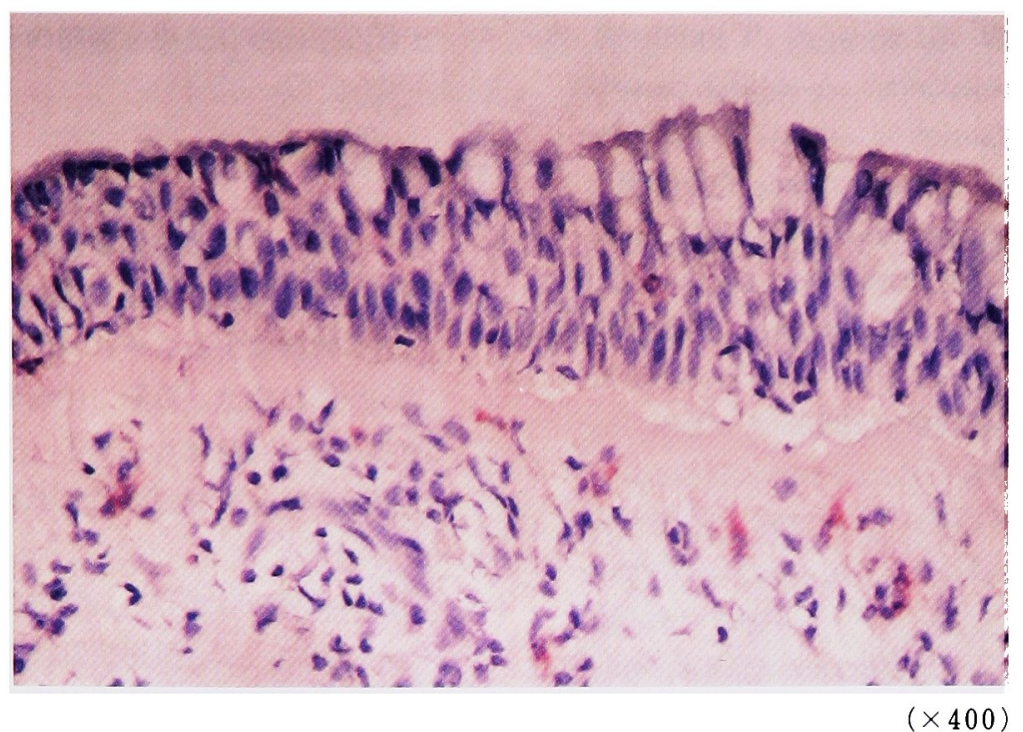

図 11 粘膜固有層における Neutrophil elastase 陽性細胞 Neutrophil elastase陽性細胞は，粘膜固有層浅層に有意に浸潤 した.

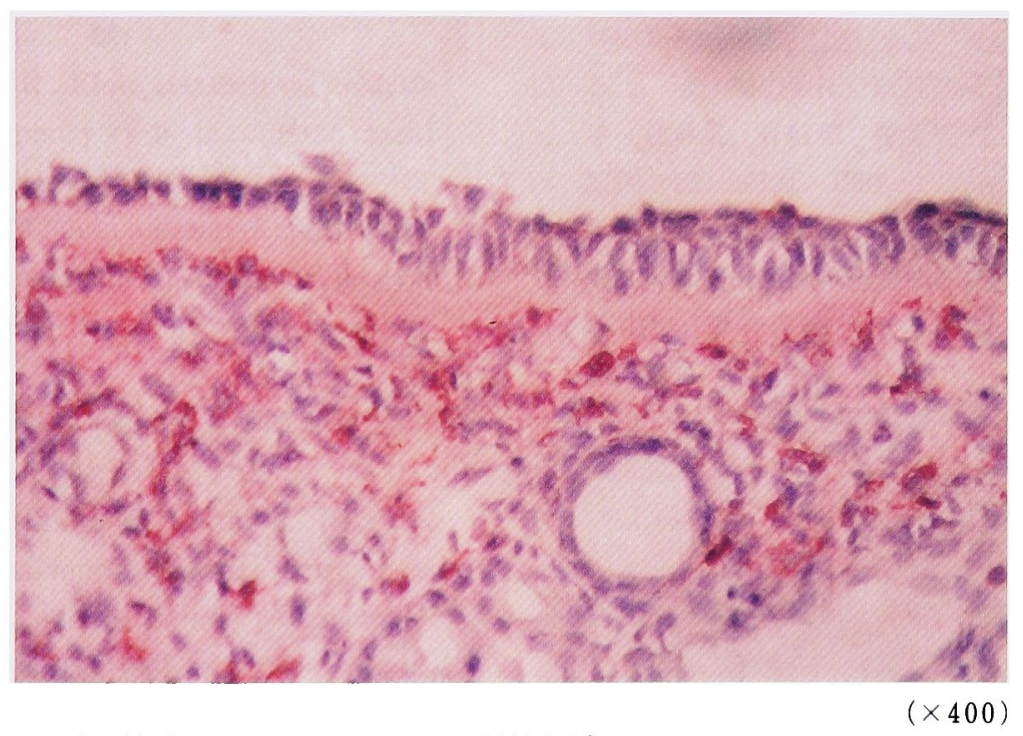

図 12 粘膜固有層における E G2 陽性細胞 E G 2 陽性細胞は, 粘膜固有層浅層, 上皮直下に有意に浸潤した。 
固有層浅層でそのほとんどが脱顆粒を示し，鼻汁中では さらに顆粒蛋白を放出していることを考えると粘膜固有 層浅層で一部は鼻汁中でその機能を果たし終えていると 思われた。

\section{まと め}

1. 通年性鼻アレルギー患者を対象として, 鼻汁中お よび鼻粘膜組織中の各浸潤細胞を免疫組織学的に比較検 討し，抗原チャレンジ即時相における変化を観察した。

2. 粘膜固有層扔上び鼻汁中に浸潤したのは, 好酸球, 好中球，マクロファージで， Tリンパ球は，粘膜固有層 と少数鼻汁中に，Bリンパ球は粘膜固有層にのみ浸潤し た。

3. 抗原チャレンジ即時相では, 好酸球が鼻汁中およ び粘膜固有層浅層に捛いて有意に增加した。

4. 鼻アレルギー患者の鼻汁中と鼻粘膜組織中では， 異なる細胞浸潤を認めたため，各浸潤細胞は，それぞれ の部位で各自の生理学的な作用を, 複雑なネットワーク を形成しながら果たし，I 型アレルギー反応に関与して いると推察された。

\section{文献}

1) Okuda M, Panwanker R: Flow cytometoric analysis of intraepithelial lymphocytes in the human nasal mucosa. Allergy 47 : 255-259, 1992.

2) Panwanker R, Okuda M : A comparative study of the characteristics of intraepithelial and lamina propria lymphocytes of the human nasal mucosa. Allergy 48: 99-105, 1993.

3）顔 真賢：ヒトアレルギー鼻粘膜上皮層浸䦌細胞の電子 顕微鏡観察.アレルギー 40：65-71，1991

4) Sigurdur J, Claus B, Hakan K, Goran K, URF P: Macrophage on the nasal mucosal surface in provoked and naturally occurring allergic rhinitis. Acta Otolaryngol (Stockh) 111: 946-953, 1991.

5) Varney VA, Jacobson MR, Sudderick RM, Robinson DS, Irani AMA, et al: Immunohistology of nasal mucosa following allergen induced rhinitis. Am Rev Respir Dis 146: 170-176, 1992.

6) Durham SR, Sun ying, Varney VA, Jacobson MR, Sudderick RM, et al: Cytokine messenger RNA expression for IL-3, IL-4, IL-5, and granulocyte/macrophage colony stimulating factor in nasal mucosa after local allergen provocation: relationship to tissue eosinophilia. J Immunol 148: 2390-2394, 1992.

7) Desreumaux P, Janin A, Colombel JF, Prin L, Plumas $J$, et al: Interleukin -5 messenger RNA expression by eosinophils in the intestinal mucosa of patient with coeliac disease. J Exp Med 175 : 293-296, 1992.

8) Bradding $\mathrm{P}$, Feather $\mathrm{IH}$, Wilson $\mathrm{S}$, Bardin $\mathrm{PG}$, Heusser $\mathrm{CH}$, et al: Immunolocalization of cytokines in the nasal mucosa of normal and perennial rhinitic subject ; the mast cell as a source of IL-4, IL-5 and IL -6 in human allergic mucosal inflammation. J Immunol 151: 3853-3865, 1993.

9) Sun Sing, Durham SR, Barkans J, Masuyama K, Jacobson $\mathrm{M}$, et al : $\mathrm{T}$ cells are the principal source of interleukin-5 mRNA in allergen-induced rhinitis. Am J Respir Cell Mol Biol 9: 356-360, 1993.

10）吉見龍一郎, 高村博光, 高崎賢治, 隈上秀伯: 鼻粘膜に おけるランゲルハンス細胞。耳宜免疫アレルギー 9 ： 102-103, 1991.

11) Lloyd AR, Oppenheim JJ : Poly's lament; The neg. lected role of the polymorphonuclear neutrophils in the afferent limb of the immune response. Immunol Today 13: 169-172, 1992.

12）小泉敦弘, 稲村直樹, 鈴木直弘, 高坂知節: 鼻アレル ギー患者の下甲介粘膜における浸潤細胞と接着分子の抗 原チャレンジによる影響，耳鼻免疫アレルギー 11： 160-161, 1993

13）石川哮，增山敬祐，鮫島靖浩：鼻アレルギー,アレル ギー性鼻炎，好酸球。牧野荏平，石川峔編，国際医学 出版：195-201頁，1991.

14）寺田修久，伊藤永子，杉山達朗，戸川清，今野昭義： 鼻アレルギ一症例の遅発相における鼻粘膜好酸球浸潤と 活性化一鼻洗浄液による検討一,アレルギー $40(3)$ : 181-190, 1991

な放本論文の要旨は，第11回日本耳鼻咽喉科免疫アレル ギー学会 (1993年; 大阪)，およびISIAN（Seoul）にて発表 した.

(1996年 4 月25日受稿 1996年11月 7 日受理)

別刷請求先 $\overline{\boldsymbol{T} 980-77}$ 仙台市青葉区星陵町 1-1 東北大学医学部耳鼻咽喉科学教室 鈴木直弘 


\title{
Immunohistological Study of Infiltrating Cells in Nasal Mucosa and Nasal Lavage Fluid of Perennial Allergic Rhinitis
}

\author{
Naohiro Suzuki, M.D., Seiichirou Nakabayashi, M.D., Shigeru Nakatsuka, M.D. \\ and Tomonori Takasaka, M.D. \\ Department of Otolaryngology, Tohoku University, School of Medicine, Sendai
}

It is well known that EG2-positive cells, CD68-positive cells and other inflammatory cells significantly increase after antigen provocation in the nasal mucosa of an allergic patient. However, there are few reports of the immunohistological study if the infiltrating cells in nasal lavage fluid are not seen. In this study, the infiltrating cells in nasal mucosa as well as in nasal lavage fluid were immunohistologically examined by means of monoclonal antibodies 30 minutes after the antigen provocation. Seven patients with perennial allergic rhinitis were challenged by an antigen disk placed on one side of the inferior turbinates and each nasal cavity was irrigated separately 30 minutes after the antigen provocation. About seven days later, these patients were operated on and the nasal mucosa was removed 30 minutes after the antigen provocation.

No marked change in CD4-and CD8-positive cells in the nasal mucosa and lavage fluid was found after provocation. On cytospin glass slides, there was a slight increase in the number of $\mathrm{CD} 68-(\mathrm{P}=0.1), \mathrm{EG} 2-(\mathrm{P}=0.09)$, and neutrophil elastase-positive $(P=0.2)$ cells. A significant increase in $E G 2$-positive cells was also seen in the superficial layer of the lamina propria $(\mathrm{P}<0.05)$ but not in the deep layer. $\mathrm{CD} 22$-positive cells were not seen on the cytospin glass slide, whereas many positive cells were observed in the deep layer of the lamina propria. These results indicate that EG2-positive cells participate strongly in the early phase of the allergic response after provocation in spite of the absence of significant changes in $\mathrm{CD} 4$-and $\mathrm{CD} 8$-positive cells. Immunohistological evaluation of nasal lavage is thought to be beneficial concerning the movement of each kind of cells. Each kind of cell is thought to fulfill the main physiological role in the epithelial layer or the lamina propria in early allergic inflammation.

Key words : nasal allergy, nasal mucosa, immunohistological stain, EG2-positive cells 